\title{
Perilaku Manusia Berkonsumsi dalam Perspektif Ekonomi Islam
}

\author{
Rahmat Ilyas \\ Fakultas Syariah dan Ekonomi Islam \\ IAIN Syaikh Abdurrahman Siddik Bangka Belitung \\ mtd_28@yahoo.com
}

\begin{abstract}
The Qur'an describes humans as biological, psychological and social beings. All three dimensions must be integrally integrated within human beings. No one can dominate the other. Like, his tendency as a biological creature is more prominent than his psychological dimension. The human dimensions depicted in the Qur'an also show that humans have diverse needs. As a biological creature, man needs things that can be healthy and protect his body. As human psychological beings need things that can nourish their intellectual and spiritual growth. As social beings humans need to socialize with other creatures.
\end{abstract}

Keywords: Human, Multi dimensional, Social

\begin{abstract}
Abstrak
Al-Quran menggambarkan manusia sebagai makhluk biologis, psikologis dan sosial. Ketiga dimensi harus terjalin secara integral dalam diri manusia. Tidak boleh yang satu mendominasi yang lainnya. Seperti, kecenderungannya sebagai makhluk biologis lebih menonjol dari dimensi psikologisnya. Multi dimensi manusia yang digambarkan al-Quran juga menunjukkan bahwa manusia memiliki kebutuhan yang bermacam-macam. Sebagai makhluk biologis, manusia membutuhkan hal-hal yang dapat menyehatkan dan melindungi tubuhnya. Sebagai makhluk psikologis manusia membutuhkan hal-hal yang dapat menyuburkan pertumbuhan intelektual dan rohaninya. Sebagai makhluk sosial manusia membutuhkan bersosialisasi dengan makhluk lainnya.
\end{abstract}

Kata Kunci: Manusia, Multi dimensi, Sosial

\section{A. Pendahuluan}

Salah satu ajaran Islam yang nampaknya tidak mendapat cukup banyak perhatian adalah yang berkenaan dengan konsep-konsep antropologis. Tiadanya perhatian yang cukup itu agaknya bukanlah karena pandangan dasar tentang eksistensi, hakikat dan makna tingkahlaku manusia tidak penting dalam ajaran islam, tetapi karena dalam dunia 
pemikiran klasik islam, masalah itu terbahas dalam berbagai tempat secara terpencarpencar, seperti dalam ilmu-ilmu tasawuf, fiqh dan ahklak, tanpa diperlakukan sebagai kajian terpisah dan disiplin spesialisasi tersendiri.

Islam memandang bahwa bumi dengan segala isinya merupakan amanah Allah kepada sang khalifah agar dipergunakan sebaik-baiknya bagi kesejahteraan manusia. Untuk mencapai tujuan suci ini, Allah swt telah memberikan aturan hidup melalui petunjuk Rasul-Nya, Muhammad saw. Petunjuk tersebut dinamakan ad-dinul Islam (agama Islam)

Dalam ajaran Islam khususnya dalam kitab suci al-Qur'an banyak kita temukan ayat-ayat yang sebenarnya membicarakan tentang manusia, mulai dari proses asal-usul manusia, tugas manusia hingga kepada bentuk tanggngjawab manusia sebagai khalifah di muka bumi ini.

\section{B. Hakikat Manusia}

Keberadaan manusia sebagai salah satu mahkluk ciptaan Tuhan di muka bumi ini mempunyai peranan penting dalam menjalankan fungsinya sebagai khalifah dimuka bumi ini. Allah swt tidak hanya mengatur tentang kehidupan yang berkaitan dengan ibadah kepada Tuhan, tetapi Allah juga mengatur bagaimana manusia menjalankan perannya diatas muka bumi ini sebagai khalifah yang bertujuan untuk dapat keselamatan dunia dan akhirat.

Telaah ayat-ayat al-Qur'an yang berbicara tentang manusia, memberi gambaran kontradiktif menyangkut keberadaannya. Disatu sisi manusia dalam al-Qur'an sering mendapat pujian Tuhan. Seperti pernyataan terciptanya manusia dalam bentuk dan keadaan yang sebaik-baiknya, kemudian penegasan tentang dimuliakannya makhluk ini dibanding dengan kebanyakan makhluk-makhluk lain. Sedang di sisi lain sering pula manusia mendapat celaan Tuhan. Seperti bahwa ia amat aniaya dan ingkar nikmat, dan sangat banyak membantah serta bersifat keluh kesah lagi kikir ${ }^{1}$

Kata manusia dalam al-qur'an terdapat tiga kata, yaitu al-basyar, an-nas dan al-ins atau al-insan. Kata al-basyar adalah gambaran manusia secara materi, yang dapat dilihat, memakan sesuatu, berjalan dan berusaha memenuhi kebutuhan kehidupannya.

Kata basyar terambil dari akar kata yang pada mulanya berarti penampakan sesuatu dengan baik dan indah. Dari akar kata yang sama lahir kata basyarah yang

${ }^{1}$ M. Quraish Shihab, Membumikan Al-Quran, (Bandung, Mizan,1994), hlm. 233 
berarti kulit. Manusia dinamai basyar karena kulitnya tampak jelas, dan berbeda dengan kulit binatang yang lain. ${ }^{2}$

Manusia dalam pengertian ini terdapat dalam surat al-Anbiya ayat 2-3:

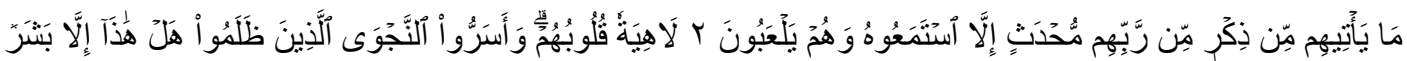

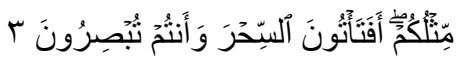

"tidak datang kepada mereka suatu ayat Al Quran pun yang baru (di-turunkan) dari Tuhan mereka, melainkan mereka mendengarnya, sedang mereka bermainmain,. (lagi) hati mereka dalam Keadaan lalai. dan mereka yang zalim itu merahasiakan pembicaraan mereka: "Orang ini tidak lain hanyalah seorang manusia (jua) seperti kamu, Maka Apakah kamu menerima sihir itu, ${ }^{3}$ Padahal kamu menyaksikannya?"'4

Selain itu manusia dalam pengertian basyar juga terdapat dalam surat Ibrahim ayat 10 :

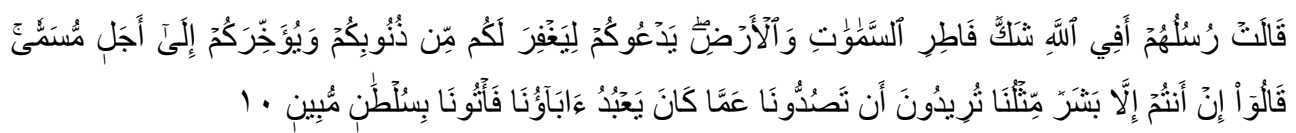

berkata Rasul-rasul mereka: "Apakah ada keragu-raguan terhadap Allah, Pencipta langit dan bumi? Dia menyeru kamu untuk memberi ampunan kepadamu dari dosa-dosamu dan menangguhkan (siksaan)mu sampai masa yang ditentukan?" mereka berkata: "Kamu tidak lain hanyalah manusia seperti Kami juga. kamu menghendaki untuk menghalang-halangi (membelokkan) Kami dari apa yang selalu disembah nenek moyang Kami, karena itu datangkanlah kepada Kami, bukti yang nyata". ${ }^{5}$

Kata an-nas juga terdapat dapat al-qur'an surat al-hujurat ayat 13:

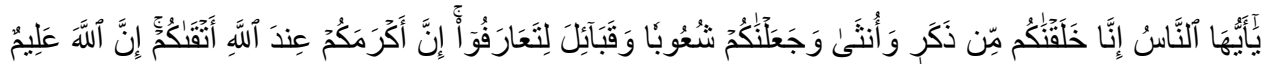

\footnotetext{
${ }^{2}$ M. Quraish Shihab Wawasan al-Quran, (Bandung, Mizan,1996), hlm. 273

${ }^{3}$ Maksud Sihir disini adalah ayat-ayat Al-qur'an

${ }^{4}$ Departemen Agama, Al-Qur'an dan Terjemahan, (Surabaya, Mekar Surabaya, 2004), hlm. 448

5 Ibid, hlm 347
} 
Hai manusia, Sesungguhnya Kami menciptakan kamu dari seorang laki-laki dan seorang perempuan dan menjadikan kamu berbangsa - bangsa dan bersuku-suku supaya kamu saling kenal-mengenal. Sesungguhnya orang yang paling mulia diantara kamu disisi Allah ialah orang yang paling taqwa diantara kamu. Sesungguhnya Allah Maha mengetahui lagi Maha Mengenal.

Penggalan ayat diatas adalah pengantar untuk menegaskan bahwa semua manusia derajat kemanusiaannya sama disisi allah, tidak ada perbedaan antara satu suku dan yang lain. Tidak ada juga perbedaan pada nilai kemanusiaan antara laki-laki dan perempuan karena semua diciptakan dari seorang laki-laki dan seorang perempuan. ${ }^{6}$

Sedangkan Kata al-insan terdapat dalam al-quran surah An-Naziat ayat 35:

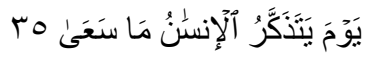

pada hari (ketika) manusia teringat akan apa yang telah dikerjakannya,

selain itu ada juga dalam surah At-Tariq ayat 5:

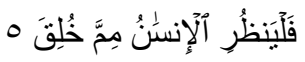

Maka hendaklah manusia memperhatikan dari Apakah Dia diciptakan? ${ }^{7}$

Manusia dalam pandangan Islam, sebagai halnya dalam agama monoteis lainnya, tersusun dari dua unsur, unsur jasmani dan unsur rohani. Tubuh manusia berasal dari materi dan mempunyai kebutuhan-kebutuhan materiil, sedangkan roh manusia bersifat immateri dan mempunyai kebutuhan spiritual. Badan, karena mempunyai hawa nafsu, bisa membawa kepada kejahatan, sedang roh, karena berasal dari unsur yang suci, mengajak kepada kesucian. Kalau seseorang hanya mementingkan hidup kematerian ia mudah sekali dibawa hanyut oleh kehidupan yang tidak bersih, bahkan dapat dibawa hanyut kepada kejahatan. ${ }^{8}$

Manusia menurut Al-Ghazali diciptakan Allah sebagai mahkluk yang terdiri dari jiwa (ruh) yang dapat diketahui dengan wawasan spritual, dan jasad. Jiwa yang menjadi hakiki manusia adalah mahkluk spritual rabbani yang sangat halus (lathifa rabbaniyah ruhaniyyah). ${ }^{9}$ Al-Ghazali membagi manusia kepada tiga golongan, yaitu:

${ }^{6}$ M. Quraish Shihab, Tafsir Al-Misbah, Volume 12, (Jakarta, Lentera Hati, 2011), hlm. 616

${ }^{7}$ Salah satu bukti pemeliharaan Allah atas manusia dan kekuasaan-Nya adalah kejadian manusia itu sendiri. Maka, karena itu manusia diperintahkan untuk memikirkan hal tersebut agar mereka dapat sampai kepada kesimpulan bahwa ada pemelihara dan ada juga pengawas yang selalu menyertainya. Lihat. M. Quraish Shihab, Tafsir Al-Misbah, Volume 15, (Jakarta, Lentera Hati, 2011), hlm. 211

${ }^{8}$ Harun Nasution, Islam di Tinjau dari Berbagai Aspeknya, (Jakarta: UI -Press, 1985), hlm. 30

${ }_{9}^{9}$ Muhammad Abul Quasem, Etika Al-Ghazali, (Bandung, Pustaka, 1988), hlm. 37 
1. Kaum awan, kaum awam dengan daya akalnya yang sederhana tidak dapat menangkap hakikat-hakikat. Mereka mempunyai sifat lekas percaya dan menurut. Golongan ini dihadapi dengan sikap member nasehat dan petunjuk

2. Kaum pilihan, yang akalnya tajam dan berpikir secara mendalam. Kaum pilihan yang daya akalnya kuat dan mendalam harus dihadapi dengan menjelaskan hikmah-hikmah.

3. Kaum penengkar yaitu dengan mematahkan argument-argumen. ${ }^{10}$

\section{Sumber Kejadian Manusia}

Manusia menurut Al-Ghazali diciptakan Allah sebagai mahkluk yang terdiri dari jiwa dan jasad. Jiwa, yang menjadi inti hakikat manusia adalah mahkluk spiritual yang rabbani yang sangat halus (lathifa rabbaniyah ruhaniyyah). Jiwa bagi Al-Ghazali adalah suatu zat (jauhar) dan bukan suatu keadaan atau aksiden, sehingga ia ada pada dirinya sendiri. Jasadlah yang adanya bergantung pada jiwa, dan bukan sebaliknya. Jiwa berada di alam spiritual, sedangkan jasad di alam materi. ${ }^{11}$

Tubuh manusia mempunyai daya-daya fisik atau jasmani, yaitu mendengar, melihat, merasa, meraba, mencium dan daya gerak baik ditempat maupun pindah tempat. Dalam pada itu ruh atau jiwa juga disebut al-nafs mempunyai dua daya, daya berpikir yang disebut akal yang berpusat dikepala dan daya rasa yang berpusat di kalbu yang berada di dada. Daya rasa yang berpusat didada dipertajam melalui ibadah(shalat, puasa, haji dan zakat), karena intisari dari semua ibadah dalam Islam ialah mendekatkan diri kepada Tuhan Yang Maha Suci, Allh swt. ${ }^{12}$

Dalam al-quran sumber kejadian manusia disebutkan dalam surah Al-Mukminun ayat 12-14:

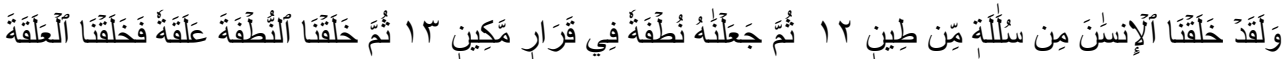

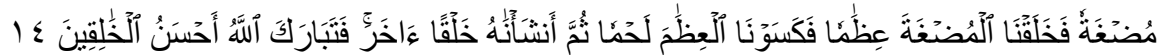
dan Sesungguhnya Kami telah menciptakan manusia dari suatu saripati (berasal) dari tanah. kemudian Kami jadikan saripati itu air mani (yang disimpan) dalam tempat yang kokoh (rahim).kemudian air mani itu Kami jadikan segumpal darah, lalu segumpal darah itu Kami jadikan segumpal daging, dan segumpal daging itu

\footnotetext{
${ }^{10}$ Hasyimsyah Nasution, Filsafat Islam, (Jakarta, Gaya Media Pratama, 1999), hlm. 86

11 Ibid, hlm. 90

12 Harun Nasution, Islam Rasional: Gagasan dan Pemikiran, (Bandung, Mizan, 1998), hlm. 37
} 
Kami jadikan tulang belulang, lalu tulang belulang itu Kami bungkus dengan daging. kemudian Kami jadikan Dia makhluk yang (berbentuk) lain. Maka Maha sucilah Allah, Pencipta yang paling baik..$^{13}$

Merujuk pada ayat diatas dapat simpulkan bahwa kualitas kehidupan manusia ditentukan melalui delapan fase kehidupan, yaitu:

1. Tanah sebagai proses awal. Persoalan ini masih dipertanyakan oleh masyarakat dimasa lalu. Namun perlu diketahui bahwa manusia dikatakan berasal dari tanah, disebabkan oleh dua hal, pertama, manusia merupakan keturunan Nabi Adam as, sedangkan Adam sendiri diciptakan dari tanah, kedua, sperma dan ovum yang menjadi cikal bakal manusia justru bersumber dari saripati makanan yang dimakan manusia. Sedangkan saripati makanan itu berasal dari tumbuhan dan hewan pemakan rerumputan. Adapun tumbuh-tumbuhan dan rumput tumbuh diatas tanah.

2. Proses yang berasal dari air mani. Setelah manusia memakan berbagai makanan yang bersumber dari tanah, akhirnya berbuah sperma dan ovum. Sprema dan ovum inilah yang disebut dengan nutfah.

3. Proses yang melekat ('alaqah). Konsekkuensi dari senggama anatar suami-istri, mengeluarkan sperma dan ovum, kemudian keduanya bercampur dan menetap di rahim setelah berubah menjadi embrio ('alaqah).

4. Proses menjadi segumpal daging (mudghah). Segumpal daging ini merupakan proses yang berasal dari 'alaqah. Segumpal daging yang sempurna itulah yang kelak berproses menjadi bayi yang sempurna panca indranya.

5. Roses menjadi tulang beulang('izham). 'izham merupakan proses kelima penciptaan manusia menurut al-qur'an. Proses ini merupakan kelanjutan dari mudghah. Dalam hal ini bentuk embrio sudah mengeras dan mguat sedikit demi sedikit sampai berubah menjadi tulang belulang.

6. Proses menjadi daging (lahmah). Lahmah merupakan fase dimana tulang belulang manusia sudah terbungkus oleh daging. Sehingga embrio sudah menyerupai ekor kecil yang perutnya butcit. Dan merupakan fase terakhir dari embrio.

${ }^{13}$ Departemen Agama, Al-Qur'an......, hlm. 475 
7. Proses peniupan roh. Fase peniupan roh adalah fase kehidupan mulai bergerak, setelah dilengkapi pendengaran, penglihatan dan hati. Pada fase ini embrio sudah berubah menjadi bayi.

8. Proses kelahiran kemuka bumi. Setelah sembilan bulan lebih berada dalam rahim. Bayi yang ada dalam rahim sudah sempurna itu lahir ke atas dunia dan mulailah ia menghirup udara kehidupan menjadi seorang manusia yang mengemban tugas sebagai khalifah Allah di muka bumi. ${ }^{14}$

\section{Kebutuhan dan Tujuan Hidup Manusia}

Al-Quran menggambarkan manusia sebagai makhluk biologis, psikologis dan sosial. Ketiga dimensi harus terjalin secara integral dalam diri manusia. Tidak boleh yang satu mendominasi yang lainnya. Seperti, kecenderungannya sebagai makhluk biologis lebih menonjol dari dimensi psikologisnya. Jika ini terjadi, manusia bisa jatuh pada derajat yang paling bawah bahkan lebih rendah dari binatang.

Disamping itu multi dimensi manusia yang digambarkan al-Quran juga menunjukkan bahwa ia memiliki kebutuhan yang bermacam-macam. Sebagai makhluk biologis misalnya, manusia membutuhkan hal-hal yang dapat menyehatkan dan melindungi tubuhnya. Sebagai makhluk psikologis manusia membutuhkan hal-hal yang dapat menyuburkan pertumbuhan intelektual dan rohaninya. Sebagai makhluk sosial manusia membutuhkan bersosialisasi dengan makhluk lainnya.

Secara garis besar, kebutuhan manusia itu dapat dibagi kepada dua, kebutuhan psikis (kejiwaan) dan kebutuhan pisik (jasmani). Ingin terhormat ingin bahagia adalah contoh kebutuhan psikis. Sedangkan ingin kenyang, ingin memiliki rumah, ingin pingin rumah, ingin punya mobil adalah contoh kebutuhan jasmani. ${ }^{15}$

Kebutuhan manusia itu bertingkat-tingkat. Pada tingkat pertama, primary needs (kebutuhan primer), manusia membutuhkan sandang, pangan, dan papan. Dikatakan primer, karena apabila tidak terpenuhi manimbulkan kerusakan pada diri manusia, bahkan dapat membawa kematian. Tingkat kedua, secondary needs (kebutuhan sekunder) adalah kebutuhan pendukung bagi kebutuhan primer. Manusia membutuhkan kendaraan untuk memudahkannya mencari nafkah. Manusia membutuhkan makan tambahan, kue, roti

14 Umar Shihab, Kontekstualitas Al-Qur'an: Kajian Tematik atas Ayat-ayat Hukum dalam Al-Qur'an, (Jakarta, Penamadani, 2005), hlm.106

15 Nur Ahmad Fadhil Lubis, Etika Bisnis Dalam Islam, (Jakarta, Hijri Pustaka Utama, 2001), hlm. 65 
untuk melengkapi makanan pokok dan sebagainya. Namun kebutuhan tingkat kedua itu muncul apabila kebutuhan primer telah terpenuhi. Demikianlah seterusnya sampai kebutuhan tingkat ketiga (tertiary needs) dalam bentuk kesenangan dan perhiasan hidup manusia. Walaupun manusia telah memiliki rumah, ia ingin rumahnya berlantaikan marmar dan beratap genteng, ingin memiliki pagar yang indah dan sebagainya.

Sepertinya kebutuhan asasi itu ditemukan dalam konsep ajaran Islam. Dalam khazanah keilmuan Islam (filsafat ilmu Islam), kebutuhan-kebutuhan tersebut disebut dengan al-daruriyat (kebutuhan primer), al-hajiyat (sekunder) dan al-tahsinat (tertier). Bedanya hanyalah, islam memandang kebutuhan primer tidak terbatas hanya hal-hal yang bersifat material, tetapi melingkupi hal-hal yang bersifat immaterial, seperti kebutuhan terhadap agama dan kebebasan dalam menjalankannya dan jiwa, disamping keturunan, harta dan akal. ${ }^{16}$

Dalam pandangan Islam, kebutuhan terhadap agama serta kebebasan dalam menjalankannya adalah kebutuhan yang paling asasi. Kebutuhan terhadap makan dan minum, walaupun tetap penting nnamun dalam pandangan Islam tetap merupakan instrument atau alat untuk mendukung terpenuhinya kebutuhan agama (kepercayaan) agar menjadi lebih baik. ${ }^{17}$

Dengan demikian, segala hal-hal yang mengancam terhadap kebutuhan agama ini harus dihindari. Malah dalam tingkat tertentu, apabila posisi agama terancam, ummatnya diperintahkan oleh kitab suci untuk mengorbankan jiwa raganya serta harta yang dimilikinya. Ini menunjukkan, betapa kebutuhan terhadap agama sabgat penting, sampaisampai kebutuhan terhadap keamanan diri harus dikorbankan.

Sampai disini sebenarnya Islam melihat kebutuhan manusia yang paling hakiki adalah memenuhi dorongan hati nuraninya untuk selalu tunduk dan patuh pada pencipta. Dan ini merupakan fitrah kemanusiaan yang tidak dapat begitu saja ditolak. Sejak manusia berada di alam rahim, kepadanya telah dibisikkan untuk pasrah dan tunduk (hanifan musliman) kepada Allah swt, pada waktu itu manusia menerimanya tanpa ada paksaan. Inilah yang sering disebut para pakar dengan perjanjian primordial.

\footnotetext{
16 Ibid, hlm. 67

17 Ibid
} 


\section{E. Tugas dan Tangungjawab Manusia}

Tugas manusia untuk memakmurkan bumi ini, sesuai dengan kehendak Allah swt dan hukum-hukum yang telah ditetapkannya, adalah untuk kebahagiaan manusia itu sendiri di dunia dan di akhirat. Kebahagian dunia dan akhirat ini menjadi tujuan umum dari syariat yang diturunkan Allah swt, bukan saja pada syariat Islam, tetapi juga syariat-syariat yang turun sebelumnya. Dengan demikian terlihat adanya keserasian dan saling terkait antara tugas manusia dan tujuan syariat yang dikehendaki Allh swt secara umum.

Dalam Islam ibadatlah yang memberikan latihan rohani yang diperlukan manusia itu. Semua ibadat yang ada dalam islam, shalat, puasa, haji, dan zakat bertujuan membuat roh manusia supaya senantiasa tidak lupa pada Tuhan, bahkan senantiasa dekat dengannya. Keadaan senantiasa dekat pada Tuhan sebagai zat yang maha suci dapat mempertajam rasa kesucian seseorang. Rasa kesucian yang kuat akan dapat memjadi rem bagi hawa nafsu untuk melanggar nilai-nilai moral, peraturan dan hukum yang berlaku dalam memenuhi keinginannya. ${ }^{18}$

Tujuan ibadat dalam Islam bukanah menyembah, tetapi mendekatkan diri dengan Tuhan, agar dengan demikian roh manusia senantiasa diingatkan kepada hal-hal yang bersih lagi suci, sehingga akhirnya rasa kesucian seseorang menjadi kuat dan tajam. Roh yang suci membawa kepada budi pekerti baik dan luhur. Oleh karena itu, ibadat disamping merupakan latihan spiritual, juga merupakan latihan moral. ${ }^{19}$

Secara umum tugas manusia sebagai khalifah yaitu:

1. Menempati kawasan atau wilayah bumi, hal sesuai dengan firman Allah dalam $\mathrm{Al}$ Baqarah ayat 36:

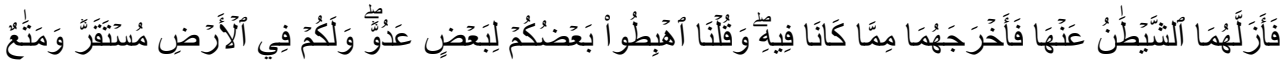

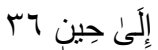

lalu keduanya digelincirkan oleh syaitan dari surga itu dan dikeluarkan dari Keadaan semula dan Kami berfirman: "Turunlah kamu! sebagian kamu menjadi musuh bagi yang lain, dan bagi kamu ada tempat kediaman di bumi, dan kesenangan hidup sampai waktu yang ditentukan."

2. Memanfaatkan kekayaan dan sumber daya alam, sebagaimana yang terkandung dalam surah $A n-N a h l$ ayat 5:

18 Harun Nasution, Islam di Tinjau ....., hlm. 31

19 Ibid, hlm. 34 
| RAHMAT ILYAS | Perilaku Manusia Berkonsumsi ....

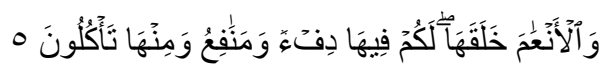

dan Dia telah menciptakan binatang ternak untuk kamu; padanya ada (bulu) yang menghangatkan dan berbagai-bagai manfaat, dan sebahagiannya kamu makan.

3. Mewujudkan kesejahteraan hidu, kemaslahatan umum dan menjaga kelestarian lingkungan hidup dari kemusnahan maupun kerusakan. Sesuai dengan firman Allah dalam surah Az-Zukhruf ayat 32:

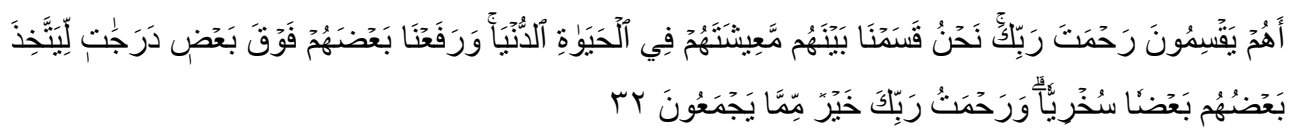

Apakah mereka yang membagi-bagi rahmat Tuhanmu? Kami telah menentukan antara mereka penghidupan mereka dalam kehidupan dunia, dan Kami telah meninggikan sebahagian mereka atas sebagian yang lain beberapa derajat, agar sebagian mereka dapat mempergunakan sebagian yang lain. dan rahmat Tuhanmu lebih baik dari apa yang mereka kumpulkan.

4. Mematuhi peraturan-peraturan Allah demi kemaslahatan umat manusia, terkandung dalam surah Ali Imran ayat 132:

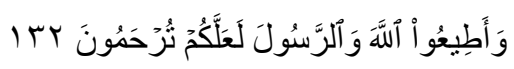

dan taatilah Allah dan rasul, supaya kamu diberi rahmat.

5. Mewujudkan kehidupan yang damai, saling menghormati dan mengembangkan sikap taa'ruf antara sesama manusia, dan menempatkan hubungan kemanusiaan sebagai hubungan keluarga besar. Sebagaimana terkandung dalam surah alHujurat ayat $13 .^{20}$

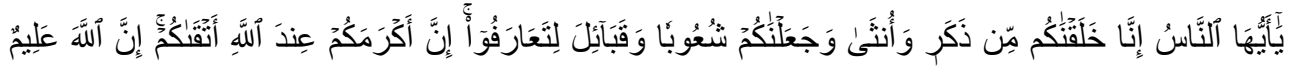
خَبِيزّ سن Hai manusia, Sesungguhnya Kami menciptakan kamu dari seorang laki-laki dan seorang perempuan dan menjadikan kamu berbangsa - bangsa dan bersuku-suku supaya kamu saling kenal-mengenal. Sesungguhnya orang yang paling mulia diantara kamu disisi Allah ialah orang yang paling taqwa diantara kamu. Sesungguhnya Allah Maha mengetahui lagi Maha Mengenal. Manusia sebagai mahkluk mukallaf berarti manusia yang bertanggungjawab dengan mempergunakan segala keistimewaannya dalam berbicara dan bertindak.

${ }^{20}$ Muhammad Tholhah Hasan, Islam dan Masalah Sumber Daya Manusia, (Jakarta, Lantabora Press, 2005), hlm. 85 
Oleh sebab itu manusia mempunyai resiko untung dan rugi yang kesemuanya itu merupakan tanggungjawabnya. Manusia sebagai khalifah Allh swt diatas bumi harus membawakan misi-misi Allah swt yang diamanahkan kepadanya dan harus menunjukkan sifat-sifat yang sempurna yang akan dapat diteladani oleh orang lain. Dari segi tanggungjawab dan amanah yang dipikul oleh manusia diatas muka bumi ini, maka manusia bisa lebih tingi nilainya dari malaikat, jika ia benar-benar bertanggungjawab dan menjalankan amanah allah swt di bumi. Tetapi bisa pula ia lebih rendah dari hewan jika tanggungjawab dan amanah ini tidak dapat dijalankannya. Oleh sebab itu kemanusiaan manusia terletak pada tanggungjawab dan amanah yang dibebankan Allah swt kepada mereka. Surah at-Tin ayat 4-5 menggambarkan keadaan manusia yang memiliki kurva naik dan turun, sesuai dengan tanggungjawab dan amanah yang ia pikul. Tatkala tanggungjawab dan amanah itu dijalankan dengan baik manusia dikatakan sebagai ahsan taqwim (penciptaan yang sempurna). Hal tersebut dapat dicapai melalui iman dan amal saleh. Manusia akan jatuh pada nilai yang paling rendah (asfala safilin) jika ia mengikuti hawa nafsu, melakukan penipuan terhadap Allah swt dan sesama manusia, merasa diri punya kekuasaan mutlak, merasa sudah berkecukupan, dan memiliki sifat-sifat yang tercela lainnya. ${ }^{21}$

Dengan mempergunakan istilah insan, al-quran menjelaskan bahwa manusia adalah mahkluk yang mengemban amanah. Menurut Fazlur Rahman yang dikutip Nur Ahmad Fadil Lubis, amanah adalah menemukan hukum alam, menguasainya atau dalam istilah al-quran mengetahui nama-nama semuanya dan kemudian menggunakannya dengan isiatif moral insani, untuk menciptakan tatanan dunia yang baik.

Sebagai khalifah Allah, manusia bertanggungjawab kepadaNya dan mereka akan diberi pahala (reward) atau azab (punishment) di akhirat kelak berdasarkan apakah kehidupan mereka didunia ini sesuai atau bertentangan dengan petunjuk yang telah diberikan Allah swt.

${ }^{21}$ Dewan Redaksi Ensiklopedi Islam, Ensiklopedi Islam, (Jakarta, PT. Ichtiar Baru van Hoeve, 2003), hlm. 162-163 


\section{F. Peran Manusia dalam Ekonomi Syariah}

Islam sangat sadar tentang dasar lahiriyah dari kehidupan manusia. Dasar lahiriyah dari kehidupan dari manusia bukannya tidak mempunyai makna bagi kesejahteraan, karena kebutuhan jasmaninya itu mempunyai arti yang sangat penting bagi kehidupannya, sehingga sebelum kebutuhannya itu terpenuhi, cita-citanya yang luhur tidak kan pernah berkembang subur. ${ }^{22}$

Butir-butir yang paling utama dari ajaran ekonomi kaum muslimin berkisar pada perhatiannya bahwa kekayaan suatu masyarakat harus dibagi secara merata diantara para warganya. Islam tidak menentang hasrat pribadi untuk memperoleh keuntungan ataupun adanya persaingan ekonomi. Islam juga tidak melarang seseorang untuk bekerja lebih keras daripada sesama yang lain, juga tidak keberatan jika ia memperoleh penghasilan yang lebih besar dari kerja kerasnya itu. Apa yang dikehendaki Islam amat sederhana, yaitu hasrat untuk memperoleh keuntungan dan nafsu untuk bersaing itu diimbangi oleh kejujuran dan belas kasihan. Karena sifat manusia secara alamiah lebih memperhatikan keuntungan dan dan persaingan itu, maka hukum-hukum sosial bertanggungjawab menjaga kejujuran dan belas kasihan tersebut tetap diperhatikan. ${ }^{23}$

Antropologi Al-Qur'an menyatakan bahwa manusia itu diciptakan dari debu, tanah liat. Lalu tuhan meniupkan ruh kedalamnya. Artinya dalam diri manusia terdapat daya tarik yang mengajak kebawah, yaitu ke debu, dan daya tarik lain yang mengajak keatas, yaitu ruh. Dengan kata lain dalam diri manusia terdapat daya tarik untuk melakukan perbuatan tidak baik, dan daya tarik lain untuk melakukan perbuatan baik. ${ }^{24}$

Aqidah adalah konsep yang paling penting dan mendasar, sebab konsep yang pertama adalah dasar pelaksanaan segala aktivitas, baik yang menyangkut ubudiah, mu'amalah, mu'asyarah hingga ahklak. Aqidah berkaitan dengan keimanan kepada Allh swt baik secara rububiyah, uluhiyah, maupun dengan nama-nama dan sifat Allah swt. Orang muslim beriman kepada rububiyah Allah terhadap segala sesuatu, dan bahwa Allah tidak mempunyai sekutu dalam keberadaan sebagai sang pencipta dan pengatur segala

${ }^{22}$ Huston Smith, Agama-agama Manusia, (Jakarta, Yayasan OborIndonesia, 195), hlm. 285

23 Ibid, hlm. 286

${ }^{24}$ H.A. Mukti Ali, Memahami Beberapa Aspek Ajaran Islam, (Bandung, Mizan, 1996), hlm. 76 
mahkluknya. Seorang muslim juga dituntut juga beriman kepada ketuhanan (uluhiyah) Allah swt, yaitu bahwa tidak ada Tuhan yang berhak disembah kecuali Allah swt. ${ }^{25}$

Pemahaman Islam mengajarkan bahwa merupakan suatu kewajiban bagi setiap muslim untuk berusaha semaksimal mungkin melaksanakan semua syariah (aturan) islam disegala aspek kehidupan, termasuk dalam pencaharian kehidupan (ekonomi). Demikian pula aspek ekonomi islam merupakan bagian ilmu sosial, tidak lepas dari konsep-konsep Islam yang harus dilaksanakan dalam bidang tersebut. ${ }^{26}$

Dalam pandangan Islam, setiap orang pada dasarnya bukan seseorang tertentu atau anggota ras, kelompok atau negara tertentu. Dengan kata lain setiap orang adalah bagian dari orang lain karena merupakan hamba Allah dari satu sumber keturunan sehingga pada dasarnya mengandung makna persatuan fundamental dan persaudaraan umat manusia. Konsep persaudaraan ini akan seimbang dengan disertai konsep keadilan. Hal ini sesuai dengan firman Allah dalam surah al-Maidah ayat 8:

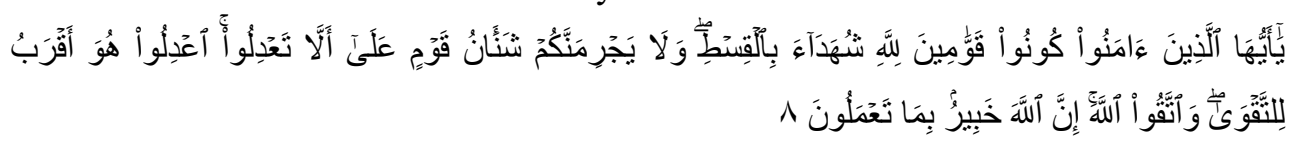

"Hai orang-orang yang beriman hendaklah kamu Jadi orang-orang yang selalu menegakkan (kebenaran) karena Allah, menjadi saksi dengan adil. dan janganlah sekalikali kebencianmu terhadap sesuatu kaum, mendorong kamu untuk Berlaku tidak adil. Berlaku adillah, karena adil itu lebih dekat kepada takwa. dan bertakwalah kepada Allah, Sesungguhnya Allah Maha mengetahui apa yang kamu kerjakan."

Syariah Islam termasuk syariah perekonomian mempunyai komitmen untuk menjadi sebab kebahagian dan kesejahteraan hidup manusia. Khususnya dalam bidang perekonomian. Tujuan syariah islam adalah menciptakan keadilan dan kesejahteraan dalam berbisnis dan berusaha. Kesejahteraan ini dipahami dari bahasa al-qur'an yaitu hayatan toyyibah (kehidupan yang baik) yang berarti tidak hanya meliputi kepuasan fisik atau jasmani saja tetapi juga kesejahteraan rohani.

\section{G. Kesimpulan}

Kata manusia dalam al-quran terdapat tiga kata, yaitu al-basyar, an-nas dan al-ins atau al-insan. Kata al-basyar adalah gambaran manusia secara materi, yang dapat dilihat, memakan sesuatu, berjalan dan berusaha memenuhi kebutuhan kehidupannya.

\footnotetext{
${ }^{25}$ Lukman Hakim, Prinsip-prinsip Ekonomi Islam, (Jakarta, Erlangga, 2012), hlm.2

26 Ibid, hlm. 3
} 
Manusia menurut Al-Ghazali diciptakan Allah sebagai mahkluk yang terdiri dari jiwa dan jasad. Jiwa, yang menjadi inti hakikat manusia adalah mahkluk spiritual yang rabbani yang sangat halus (lathifa rabbaniyah ruhaniyyah). Jiwa bagi al-ghazali adalah suatu zat (jauhar) dan bukan suatu keadaan atau aksiden, sehingga ia ada pada dirinya sendiri. Jasadlah yang adanya bergantung pada jiwa, dan bukan sebaliknya. Jiwa berada di alam spiritual, sedangkan jasad di alam materi

Dalam pandangan Islam, kebutuhan terhadap agama serta kebebasan dalam menjalankannya adalah kebutuhan yang paling asasi. Kebutuhan terhadap makan dan minum, walaupun tetap penting nnamun dalam pandangan islam tetap merupakan instrument atau alat untuk mendukung terpenuhinya kebutuhan agama (kepercayaan) agar menjadi lebih baik.

Butir-butir yang paling utama dari ajaran ekonomi kaum muslimin berkisar pada perhatiannya bahwa kekayaan suatu masyarakat harus dibagi secara merata diantara para warganya. Islam tidak menentang hasrat pribadi untuk memperoleh keuntungan ataupun adanya persaingan ekonomi. Islam juga tidak melarang seseorang untuk bekerja lebih keras daripada sesama yang lain, juga tidak keberatan jika ia memperoleh penghasilan yang lebih besar dari kerja kerasnya itu. Apa yang dikehendaki islam amat sederhana, yaitu hasrat untuk memperoleh keuntungan dan nafsu untuk bersaing itu diimbangi oleh kejujuran dan belas kasihan.

Dalam pandangan Islam, setiap orang pada dasarnya bukan seseorang tertentu atau anggota ras, kelompok atau negara tertentu. Dengan kata lain setiap orang adalah bagian dari orang lain karena merupakan hamba Allah dari satu sumber keturunan sehingga pada dasarnya mengandung makna persatuan fundamental dan persaudaraan umat manusia. 


\section{DAFTAR PUSTAKA}

Abul Quasem Muhammad, Etika Al-Ghazali, Bandung, Pustaka, 1988

Ahmad Fadhil Lubis Nur, Etika Bisnis Dalam Islam, Jakarta, Hijri Pustaka Utama, 2001

Ali H.A. Mukti, Memahami Beberapa Aspek Ajaran Islam, Bandung, Mizan, 1996

Departemen Agama, Al-Qur'an dan Terjemahan, Surabaya, Mekar Surabaya, 2004

Hakim Lukman, Prinsip-prinsip Ekonomi Islam, Jakarta, Erlangga, 2012

Huston Smith, Agama-agama Manusia, Jakarta, Yayasan Obor Indonesia, 1995

Nasution Harun, Islam di Tinjau dari Berbagai Aspeknya, Jakarta: UI -Press, 1985

Islam Rasional: Gagasan dan Pemikiran, Bandung, Mizan, 1998

Nasution Hasyimsyah, Filsafat Islam, Jakarta, Gaya Media Pratama, 1999

Redaksi Ensiklopedi Islam Dewan, Ensiklopedi Islam, Jakarta, PT. Ichtiar Baru van Hoeve, 2003

Shihab Umar, Kontekstualitas Al-Qur'an: Kajian Tematik atas Ayat-ayat Hukum dalam Al-Qur'an, Jakarta, Penamadani, 2005

Shihab M. Quraish, Membumikan al-Quran, Bandung, Mizan,1994

Wawasan al-Quran, Bandung, Mizan,1996

, Tafsir Al-Misbah, Volume 12, Jakarta, Lentera Hati, 2011

, Tafsir Al-Misbah, Volume 15, Jakarta, Lentera Hati, 2011

Tholhah Hasan Muhammad, Islam dan Masalah Sumber Daya Manusia, Jakarta, Lantabora Press, 2005 